\title{
Diversity of $\beta$-lactam resistance genes in gram-negative rods isolated from a municipal wastewater treatment plant
}

\author{
Marta Piotrowska $^{1} \cdot$ Sylwia Kowalska ${ }^{1} \cdot$ Magdalena Popowska $^{1}$ (D) \\ Received: 13 November 2018 / Accepted: 7 February 2019 /Published online: 26 February 2019 \\ (C) The Author(s) 2019
}

\begin{abstract}
Urban wastewater treatment plants (UWTPs) are considered hot spots for the accumulation and transfer of antibiotic resistant bacteria and their genes. We investigated the prevalence, diversity, and genomic localization of $\beta$-lactamase resistance genes in wastewater from different parts of an UWTP, such as raw wastewater, wastewater from biological reactor, and treated wastewater, collected from the UWTP of Warsaw, Poland. In this study, we focused on gram-negative rods, mainly Enterobacteriaceae, and used Multiplex PCR to identify various $\beta$-lactamase resistance genes $(b l a)$. Susceptibility to a number of antibiotics and genomic localization of $\beta$-lactamase resistance genes were then determined using disc-diffusion and Southern hybridization methods, respectively. No differences in the frequency of different types of bla genes between the sampling points were discerned. Three new variants of $\beta$-lactamase genes $\left(b_{\mathrm{CMY}-157}, b l a_{\mathrm{MOX}-13}\right.$, and $\left.b l a_{\mathrm{FOX}-15}\right)$ were identified. Four bla genes $\left(b l a_{\mathrm{TEM}-12}, b l a_{\mathrm{TEM}-30}, b l a_{\mathrm{TEM}-47 / 68}, b l a_{\mathrm{ACT}}\right)$ that had never been found in UWTPs were identified in this study. Nine of the identified bla genes had been found in the same environment previously. The $b_{\text {FOX-15 }}$ variant on a Kluyvera sp. plasmid and bla $a_{\mathrm{GES}}$ type on Raoultella spp. plasmids were observed for the first time in these genera. There was a decrease in the number of multidrug resistant strains in the effluent compared to the influent. Finally, a significantly higher number of cefotaxime and carbapenem unsusceptible strains were detected in the influent than in the effluent. The results strongly support the hypothesis of UWTPs as a hot spot for antibiotic resistant genes (ARGs) and antibiotic resistant bacteria (ARB) accumulation and indicate that $\beta$-lactamase genes are widely disseminated among gram-negative rods isolated from this environment.
\end{abstract}

Keywords $\beta$-Lactamases $\cdot$ Enterobacteriaceae $\cdot$ Plasmid $\cdot$ Antibiotic resistance gene $\cdot$ Horizontal gene transfer $\cdot$ Wastewater treatment plant

\section{Introduction}

Antibiotic resistance genes (ARGs) and antibiotic resistance bacteria (ARB) are considered critical threats to global public health. For this reason, international organizations and actions, including the World Health Organization (WHO), the European Committee on Antimicrobial Susceptibility

Electronic supplementary material The online version of this article (https://doi.org/10.1007/s13213-019-01450-1) contains supplementary material, which is available to authorized users.

Magdalena Popowska magdapop@biol.uw.edu.pl

1 Department of Applied Microbiology, Institute of Microbiology, Faculty of Biology, University of Warsaw, I. Miecznikowa 1, 02-096 Warsaw, Poland
Testing (EUCAST), the Food and Agriculture Organization of the United Nations (FAO), and NEREUS COST Action ES1403 (http://www.nereus-cost.eu/), carry out and recommend numerous antimicrobial resistance surveillance programs (NEREUS COST Action ES1403 2018; European Committee on Antimicrobial Susceptibility Testing 2018; Food and Agriculture Organization of the United Nations 2018; World Health Organization 2017). An important part of these efforts is to monitor and identify antimicrobial "hot spots," mainly those affected by anthropogenic activities.

Previous studies indicated that wastewater treatment plants (WWTPs) are one of the key reservoirs of both ARB and ARGs (Baquero et al. 2008; Michael et al. 2013). Diverse genes that encode resistance to all major classes of antibiotics have been identified in sewage (Zhang et al. 2009). The efficiency of removing ARGs during the wastewater treatment process depends on the 
treatment technology and the sources of sewage coming to a WWTP (hospital, municipal effluent) (Novo et al. 2013; Barancheshme and Munir 2017; Michael-Kordatou et al. 2018). These genes have been found in both environmental and pathogenic strains. The latter may flow to a WWTP with hospital sewage. While ARGs are considered to be easily acquired by bacteria, they are difficult to eliminate even when the selective pressure is removed (Aminov and Mackie 2007). Under the circumstances, cases of transmission of ARGs between environmental and clinical strains represent a serious threat to public health. Mobile genetic elements (MGEs) were postulated as important vectors for ARG exchange between bacterial strains in WWTP settings (Perry and Wright 2013). Research into the wastewater resistome and the associated "mobilome" is currently underway. The importance of such studies is emphasized by the increasing number of multidrug resistant (MDR) strains of clinically relevant bacteria that are spreading around the world.

Together with tetracyclines, macrolides, and sulfonamides, $\beta$-lactams are important antibiotics in human and veterinary medicine. The number and diversity of $\beta$ lactamase genes are significantly higher compared to ARGs from other antibiotic classes (NCBI Bioproject PRJNA313047). As the largest group of diverse and specific resistance determinants in bacteria, $\beta$-lactamase genes are intensively explored in terms of dissemination mechanisms in the environment. B-lactamases are unique also because of their broad spectrum of activity against $\beta$ lactams and - consequently-very high mutation frequency (Gniadkowski 2008; Bush and Jacoby 2010). The Bacterial Antimicrobial Resistance Reference Gene Database (Accession: PRJNA313047; ID: 313047) currently gathers more than 2000 renumbered $\beta$-lactamase gene (bla) sequences belonging to 35 types and numerous variants. The number continues to grow. B-lactamase resistance genes belonging to the $\mathrm{AmpC}$, ESBL, KPC, and NDM groups have been found in bacteria identified in wastewater (Zhang et al. 2009; Picão et al. 2013; Khan and Parvez 2014; Amador et al. 2015; Varela et al. 2016; Piotrowska et al. 2017). However, our understanding of the diversity of types and variants is still limited.

Investigating these differences at the local level is crucial for assessing the risk of spreading of bla and other ARGs and the efficiency of ARG removal from wastewater treatment systems. When such results are analyzed at a global level, the spread and proliferation of ARGs in the environment may be controlled. Consequently, the main aim of our study was to characterize the diversity and genomic localization of a wide range of $\beta$-lactamase genes in bacteria that had been isolated from wastewater samples collected from different parts of a conventional activated sludge UWTP, such as raw sewage, wastewater from a biological reactor, and treated wastewater.

\section{Materials and methods}

\section{Characterization and identification of bacterial isolates}

In this study, we analyzed 58 ceftazidime- or meropenemresistant bacterial strains isolated from a municipal UWTP. All described strains were isolated from raw sewage (influent), wastewater from a biological reactor (bioreactor) or treated wastewater (effluent) from the Czajka UWTP located in Warsaw, Poland. Studied UWTP is a secondary treatment facility-CAS WWTP (Conventional Activated Sludge), which collects domestic, urban, and hospital sewage from Warsaw and suburban area. The strains were isolated in four time periods (September 2011, October 2011, April 2014, and June 2014) from three sampling points (influent, bioreactor and effluent). The isolates were harvested from R2Agar complete medium (Graso Biotech, Poland) supplemented with meropenem or ceftazidime at a final concentration of $4 \mu \mathrm{g} \mathrm{ml}^{-1}$ and $16 \mu \mathrm{g} \mathrm{ml}^{-1}$, respectively. The antibiotic concentrations were selected based on M100 Clinical and Laboratory Standards Institute guidelines for Enterobacteriaceae (CLSI 2017). In this report, ceftazidimeand meropenem-resistant strains were analyzed. Identification to the genus level was performed based on partial 16S rRNA sequences obtained with the use of common primers ( $8 \mathrm{~F}$ and U1492R) and under amplification conditions described elsewhere (James 2010). PCR products of expected size were sequenced at Genomed (Warsaw, Poland). Sequence analysis and assembly were performed using Clone Manager 8 (Sci-Ed Software, USA) and FinchTV chromatogram viewer (Geospiza, USA). Determination to the genus level was performed using a minimum $95 \%$ threshold in identity with the relevant nucleotide sequence from non-redundant nucleotide GenBank collection database (nr/nt) using BLAST N tool (Altschul et al. 1990). The approach based on 16S rRNA gene sequencing is widely used for bacterial classification, but it has low phylogenetic power at the species level and poor discriminatory power for some genera, such as Enterobacteriaceae (Janda and Abbott 2007; Srinivasan et al. 2015). In this case, we decided to assign isolates only to the genus level based on $95-100 \%$ identity score. All sequences were deposited in GenBank under the following numbers: MF457824-MF457850 and MF457852-MF457885 (Tables 1S-3S).

\section{Detection of $\beta$-lactamase genes and integrons}

Identification of bla genes was performed using PCR amplification methods, mainly Multiplex PCR, as described elsewhere (Perez-Perez and Hanson 2002; Dallenne et al. 2010). In this study, five Multipex reactions were performed using specific primers (Table 4S). Moreover, the identified 
Raoultella spp. isolates were screened for the presence of chromosomal bla genes, such as bla $a_{\mathrm{ORN}}$ (characteristic of $R$. ornithinolytica) and bla $a_{\mathrm{PLA}}$ (characteristic of $R$. planticola), with primers and under reaction conditions described previously (Walckenaer et al. 2008). Additionally, the identified strains were screened for the presence of integrase genes - int II, int 2 , and int $I 3$ - using the previously described primers and conditions (Henriques et al. 2006). Genomic DNA of clinical strains that carry selected $\beta$ lactam resistance genes, obtained from the National Medicines Institute (Warsaw, Poland) (Table 5S), was used as a positive control. Escherichia coli ATCC 25922 strain was used as a negative control in Multiplex PCR reactions. In turn, genomic DNA of Aeromonas spp. strains with the confirmed presence of integrase genes was used as a positive control for integrase genes (Piotrowska et al. 2017). Specific PCR products were sequenced to avoid false positive results. Sequence assembly and analysis were carried out with Clone Manager version 8 (Sci-Ed Software, USA) and FinchTV chromatogram viewer (Geospiza, USA). Determination of the bla types and variants was performed using a $100 \%$ threshold in identity with the relevant amino acid sequence from Lahey Clinic beta-lactamse protein sequence database (no longer exist; data transfer into NCBI Bioproject PRJNA31147) with BLAST X tool (Lahey Clinic 2015; Altschul et al. 1990). All of the protein sequences that had less than $100 \%$ identity with sequences from the database were classified as new variants. New variants of bla genes were deposited in GenBank under the following numbers: MF795086 (bla $\left.a_{\mathrm{MOX}-13}\right)$, MF795087 (bla $\left.a_{\mathrm{FOX}-15}\right)$, and

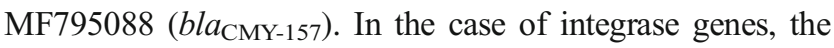
amplicons were sequenced and compared with non-redundant protein sequences gathered in the GenBank database (nr) using BLAST X tool.

\section{Antibiotic susceptibility of the resistant strains}

The susceptibility profiles of 54 strains to 12 antibiotics were determined using the agar diffusion method and Clinical and Laboratory Standards Institute guidelines M100 for Enterobacteriaceae and Acinetobacter spp. (CLSI 2017). The following antibiotics were used: amikacin (AK, $30 \mu \mathrm{g})$, gentamicin $(\mathrm{CN}, 10 \mu \mathrm{g})$, chloramphenicol $(\mathrm{C}, 30 \mu \mathrm{g})$, ciprofloxacin (CIP, $5 \mu \mathrm{g}$ ), tetracycline (TET, $30 \mu \mathrm{g}$ ), ceftazidime (CAZ, $30 \mu \mathrm{g}$ ), cefotaxime (CTX, $30 \mu \mathrm{g}$ ), cefepime (FEP, $30 \mu \mathrm{g}$ ), aztreonam (AZT, $30 \mu \mathrm{g}$ ), imipenem (IMP, $10 \mu \mathrm{g}$ ), ertapenem (ERT, $10 \mu \mathrm{g}$ ), and meropenem (MEM, $10 \mu \mathrm{g}$ ). According to CLSI 2017 guidelines, there are no Acinetobacter spp. breakpoints for aztreonam, ertapenem, and chloramphenicol. This resulted in the exclusion of the three antibiotics from the Acinetobacter spp. susceptibility profile testing. Susceptibility profiles for Pseudomonas spp. (other than Pseudomonas aeruginosa), Ochrobactrum spp., and Shewanella spp. were not determined, because there are no antibiotic agar diffusion guidelines for these bacteria. Inhibition zones smaller than $\mathrm{S}$ (susceptible) and larger than R (resistant) were classified as intermediate resistance (I) and excluded from the resistance percentage calculations. Pseudomonas aeruginosa ATCC 27853 and Escherichia coli ATCC 25922 strains were used for quality control. The multiple antibiotic resistance index (MAR index) for a given isolate was calculated as the number of antibiotics to which the isolate was resistant (a) divided by the total number of antibiotics against which the isolate was tested (b) (Zhang et al. 2015). The MAR index was obtained based on the results of disc diffusion analysis.

\section{Plasmid isolation and Southern hybridization protocol}

To determine the location of $\beta$-lactamase resistance genes, plasmid DNA from all strains was isolated. Extrachromosomal DNA was extracted and purified using Plasmid Mini AX Gravity kit (A\&A Biotechnology, Poland), according to the manufacturer's instruction. The isolated plasmids were separated by electrophoresis in $0.8 \%$ agarose gels, stained with ethidium bromide and visualized using a UV transilluminator. Probes for Southern hybridization were obtained from ARGs PCR products identified in the earlier steps of this work and incubated with digoxigenin (DIG). Separated plasmid DNA was transferred to a nylon membrane (Roche Diagnostics GmbH, Germany) and hybridized with the probes. Preparation of (DIG)-labeled probes, hybridization, and visualization was performed using DIG-High Prime DNA Labeling and Detection Starter Kit I (Roche Applied Science, Germany). The PCR products utilized to create the probes were further used as positive controls.

\section{Statistical analysis}

Statistical analyses were performed using the lme 4 package in R 3.3.3 software (R Core Team, 2017). The frequencies of antibiotic resistance phenotypes and ARGs were compared among strains isolated from influent, bioreactor, and effluent. The chi-square test was used to determine the significance of the distribution of ARGs and phenotypes. In this work, the level of significance was $p$ value $<0.05$.

\section{Results}

\section{Genus-level diversity of the identified strains}

Of 58 strains that had been chosen for this study, 26 were found in raw wastewater, 23 were detected in a bioreactor, and nine were identified in treated wastewater (Tables 1S$3 \mathrm{~S}$ ). Bacteria of the Enterobacteriaceae family predominated at each sampling point, and their number was 24,20 , and 7 in raw wastewater, bioreactor, and treated wastewater, 
respectively. Based on $16 \mathrm{~S}$ rRNA sequencing results, the identified genera of this family most likely belonged to Citrobacter spp., Raoultella spp., Kluyvera spp., Enterobacter spp., Klebsiella spp. Escherichia spp., and Serratia sp. The most frequent were Raoultella spp. (17 strains) and Citrobacter spp. (11 strains). Moreover, only three genera and one species were observed at each of the three sampling points, i.e., Citrobacter spp., Enterobacter spp., Klebsiella spp., and Escherichia spp.

Other isolated strains belonged to Pseudomonas spp., Shewanella sp., Ochrobactrum sp., and Acinetobacter spp. and were the minority. Pseudomonas spp. were found in raw wastewater (one strain) and bioreactor (two strains). The remaining genera were identified at only one WWTP sampling point.

\section{$\beta$-Lactamase resistance determinants}

The main part of this study was the identification of the wide range of $\beta$-lactamase resistance genes (bla) within the selected strains. As a result of our investigation, 128 bla genes were identified among the studied isolates (Table 1). From among 24 bla gene types that were chosen for molecular screening, the following 13 types were identified: $b l a_{\mathrm{TEM}}, b l a_{\mathrm{OXA}}$, bla $a_{\mathrm{SHV}}$, bla $_{\mathrm{CTX}-\mathrm{M}}$, bla $a_{\mathrm{CMY}}, b l a_{\mathrm{MOX}}, b l a_{\mathrm{FOX}}, b a_{\mathrm{ACT}}, b l a_{\mathrm{GES}}$, $b l a_{\mathrm{PER}}, b l a_{\mathrm{VIM}}, b l a_{\mathrm{KPC}}$, and $b l a_{\mathrm{ORN}}$. Bla $a_{\mathrm{TEM}}$ genes were found in 33 strains and were the most frequent bla gene types recovered from all strains. Genes that were found at all three sampling points belonged to $b l a_{\mathrm{TEM}}, b l a_{\mathrm{OXA}}, b l a_{\mathrm{SHV}}, b l a_{\mathrm{CMY}}$, and $b l a_{\mathrm{VIM}}$ types with the predominance of bla Statistical analysis showed there were no significant differences in the number of each bla gene type between the sampling points $(p<0.05)$.

Genes of bla $a_{\text {TEM }}$ type were found in all identified bacterial genera besides Pseudomonas spp. and Acinetobacter spp. (Tables 1S-3S). Using the chosen pair of primers, in most of the sequenced $b l a_{\mathrm{TEM}}$ amplicons, we were unable to unambiguously determine any specific variant of this gene. However, in two isolates from the influent and one from the effluent, we identified three $b l a_{\mathrm{TEM}}$ variants based on the obtained partial sequences. BLASTx alignment of bla $a_{\mathrm{TEM}}$ sequence from Shewanella sp. 192 showed $100 \%$ identity to the sequence of TEM-12 $\beta$-lactamase variant (GenBank Protein accession number AAA25053.1, GenBank bla gene accession number M88143). Analogously, bla $a_{\mathrm{TEM}}$ sequences from Escherichia sp. 149 and Enterobacter sp. 480 showed 100\% identity to TEM-30 (CAD24670.1, AJ437107) and TEM-116 (AAB39956.1, U36911) sequences, respectively. Moreover, in Raoultella sp. 7.42 strain isolated from influent, the BLASTx alignment of $b l a_{\mathrm{TEM}}$ sequence showed a $100 \%$ identity to the sequences of two $\beta$-lactamase variants: TEM-47 (CAA71322.1, Y10279) and TEM-68 (CAB92324.1, AJ239002), whose variable amino acids are located outside the translated PCR product.
Table 1 Number of $\beta$-lactamase resistance and integrase gene variants and types among strains isolated from UWTP with division into three sampling points

\begin{tabular}{|c|c|c|c|c|}
\hline ARG type & Influent & Bioreactor & Effluent & Summary \\
\hline$b l a_{\mathrm{TEM}}$ & 13 & 17 & 3 & 33 \\
\hline$b l a_{\text {TEM-1-like }}$ & 10 & 17 & 2 & 29 \\
\hline$b l a_{\mathrm{TEM}-12}$ & 1 & 0 & 0 & 1 \\
\hline$b l a_{\mathrm{TEM}-30}$ & 1 & 0 & 0 & 1 \\
\hline$b l a_{\mathrm{TEM}-47 / 68}$ & 1 & 0 & 0 & 1 \\
\hline$b l a_{\mathrm{TEM}-116}$ & 0 & 0 & 1 & 1 \\
\hline$b l a_{\mathrm{OXA}}$ & 9 & 3 & 1 & 13 \\
\hline$b l a_{\mathrm{SHV}}$ & 5 & 1 & 3 & 9 \\
\hline$b l a_{\text {SHV-11-like }}$ & 0 & 1 & 0 & 1 \\
\hline$b a_{\mathrm{SHV}-12-\mathrm{like}}$ & 5 & 0 & 3 & 8 \\
\hline$b l a_{\mathrm{CTX}-\mathrm{M}}$ & 14 & 0 & 1 & 15 \\
\hline$b l a_{\text {CTX-M-15-like }}$ & 10 & 0 & 1 & 11 \\
\hline$b l a_{\text {CTX-M-1-like }}$ & 1 & 0 & 0 & 1 \\
\hline$b l a_{\mathrm{CTX}-\mathrm{M}-3-\text { like }}$ & 2 & 0 & 0 & 2 \\
\hline$b l a_{\text {CTX-M-27-like }}$ & 1 & 0 & 0 & 1 \\
\hline$b l a_{\mathrm{GES}}$ & 2 & 11 & 0 & 13 \\
\hline bla $a_{\mathrm{PER}}$ & 1 & 0 & 0 & 1 \\
\hline$b l a_{\mathrm{PER}-1 / 5}$ & 1 & 0 & 0 & 1 \\
\hline$b l a_{\mathrm{CMY}}$ & 6 & 2 & 1 & 9 \\
\hline$b l a_{\mathrm{CMY}-4}$ & 1 & 0 & 0 & 1 \\
\hline$b l a_{\mathrm{CMY}-39}$ & 0 & 0 & 1 & 1 \\
\hline$b l a_{\mathrm{CMY}-40}$ & 0 & 1 & 0 & 1 \\
\hline$b l a_{\mathrm{CMY}-139}$ & 0 & 1 & 0 & 1 \\
\hline$b l a_{\mathrm{CMY}-157}$ & 2 & 0 & 0 & 2 \\
\hline$b l a_{\mathrm{CMY}-42 / 146 / 145}$ & 1 & 0 & 0 & 1 \\
\hline$b l a_{\mathrm{CMY}-2-\text { like }}$ & 1 & 0 & 0 & 1 \\
\hline$b a_{\mathrm{CMY}-65 / 75 / 89 / 113}$ & 1 & 0 & 0 & 1 \\
\hline$b l a_{\mathrm{MOX}}$ & 0 & 0 & 1 & 1 \\
\hline$b l a_{\mathrm{MOX}-13}$ & 0 & 0 & 1 & 1 \\
\hline$b l a_{\mathrm{FOX}}$ & 0 & 0 & 1 & 1 \\
\hline$b l a_{\mathrm{FOX}-15}$ & 0 & 0 & 1 & 1 \\
\hline$b l a_{\mathrm{ACT}}$ & 0 & 1 & 0 & 1 \\
\hline$b l a_{\mathrm{VIM}}$ & 1 & 3 & 3 & 7 \\
\hline$b l a_{\mathrm{VIM}-1-\mathrm{like}}$ & 0 & 1 & 3 & 4 \\
\hline$b l a_{\mathrm{VIM}-2-\text { like }}$ & 1 & 2 & 0 & 3 \\
\hline$b l a_{\mathrm{KPC}}$ & 0 & 12 & 1 & 13 \\
\hline$b l a_{\mathrm{KPC}-2 \text {-like }}$ & 0 & 12 & 1 & 13 \\
\hline$b l a_{\text {ORN }}$ & 3 & 10 & 0 & 12 \\
\hline intI & 18 & 13 & 9 & 40 \\
\hline intII & 7 & 0 & 0 & 7 \\
\hline intIII & 1 & 1 & 2 & 4 \\
\hline
\end{tabular}

Total number of beta-lactamase and integrase gene types were marked in italics

The remaining $b l a_{\mathrm{TEM}}$ sequences were $100 \%$ identical to those of TEM-1 (AAB59737.1, J01749) and many different $\beta$ lactamase variants that have their variable regions outside the 
Fig. 1 Number of bla genes of different types identified in bacteria from influent (orange), bioreactor (violet), and effluent (green)

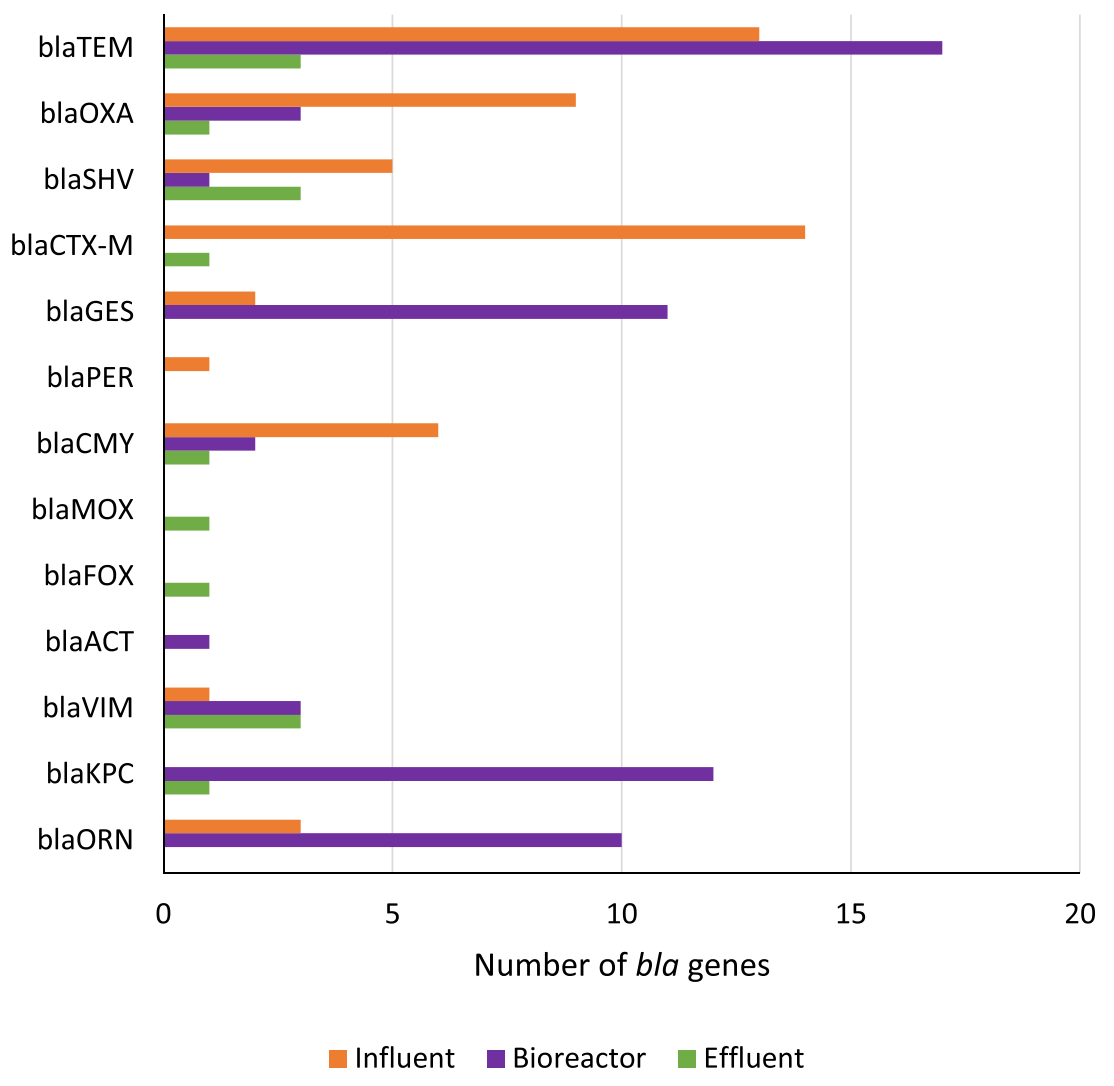

obtained PCR products. In these cases, the remaining variants were named $b l a_{\text {TEM-1-like }}$.

As for the bla $a_{\text {OxA }}$ genes, they were found only within Enterobacteriaceae strains, including nine strains from the influent, three from the bioreactor, and one from the effluent. However, all identified $b a_{\text {OXA }}$ sequences shared $100 \%$ similarity with the sequences of OXA-1 (AAA91586.2, J02967), OXA-16 (AF043100.1, AF043100), OXA-113 (ABW70410.1, EF653400), and OXA-320 (AGR55864.1, KF151169) variants of this $\beta$-lactamase. Again, the determination of bla $a_{\text {OXA }}$ variant of the gene based on the obtained partial sequence was impossible.

In the case of $b l a_{\text {SHV }}$ genes, all nine sequences were identified within the Enterobacteriaceae family, with five isolates from the influent, one from the bioreactor, and three from the effluent. Three bla $_{\text {SHV }}$ genes were found in Klebsiella spp. and are intrinsic in this genus. All $b l a_{\mathrm{SHV}}$ gene sequences from the influent and effluent were $100 \%$ identical to the sequences of SHV-12 (CAI76927.1, AJ920369) and a couple different $\beta$-lactamase variants. However, one Klebsiella sp. T12 strain from the bioreactor carried $b l a_{\mathrm{SHV}}$ whose sequences were $100 \%$ identical to those of SHV-11 (CAA66729.1, X98101) and a couple of different SHV $\beta$-lactamases with the same predicted amino acid sequence of the fragment of the sequence that was obtained in this study. These genes will be further referred to as $b l a_{\mathrm{SHV}-11-l i k e}$ and $b_{\text {SHV-12-like. }}$
$B l a_{\mathrm{CTX}-\mathrm{M}}$ was another numerous group of bla genes that were identified only in Enterobacteriaceae strains with a predominance in raw wastewater (14 strains). Bla $a_{\text {CTX-M }}$ was also found in one Escherichia sp. T24 strain from the effluent. In ten identified strains, $b l a_{\mathrm{CTX}-\mathrm{M}}$ gene sequences were $100 \%$ identical to those of CTX-M-15 (AAL02126.1, AY044436), CTX-M-28 (CAD70280.1, AJ549244), and a couple different variants, which made the final determination of this variant impossible. One Escherichia sp. 139 strain had a bla $a_{\text {CTX-M }}$ gene whose sequence was $100 \%$ identical to those of CTX-M-1 (CAA63262.1, X92506), CTX-M-61 (ABN09669.1, EF219142), and CTX-M138 (WP_070064534.1, NG_051737.1). This was a different variant of the bla $a_{\mathrm{CTX}-\mathrm{M}}$ gene than the previous 12 , but again, it could not be fully determined. Finally, there were two strains of Kluyvera sp. 102 and Klebsiella sp. 133 in which bla ${ }_{\text {CTX-M gene }}$ sequences were $100 \%$ identical to those of CTX-M-3 (CAA71321.1, Y10278), CTX-M-22 (AAL86924.1, AY080894), CTX-M-66 (ABQ45409.1, EF576988), and CTXM-162 (AKO63213.1, KP681697). Again, determination of the variant from this part of the gene was impossible. All the foregoing CTX-M $\beta$-lactamases belonged to the group 1 CTX-M enzymes (Bonnet 2004). However, in one Escherichia sp. 6.42 strain, there was a $b l a_{\mathrm{CTX}-\mathrm{M}}$ gene that encoded a $\beta$-lactamase with 100\% sequence identity to CTX-M-27 (AAO61597.1, AY156923), CTX-M-98 (ADO17948.1, HM755448), and a couple of different variants that belonged to group nine of this type of enzymes. 
In the case of $b l a_{\mathrm{GES}}$ sequences, it was impossible to determine the gene variant based on the obtained partial sequences. However, all 13 bla $_{\mathrm{GES}}$ sequences were $100 \%$ identical to those of GES-1 (AAF27723.1, AF156486) and some other GES $\beta$ lactamases variants. Most of the $b l a_{\mathrm{GES}}$ genes were identified within Raoultella spp. strains (10 from the bioreactor and one from the influent). In addition, two more $b l a_{\mathrm{GES}}$ were found: one in Klebsiella spp. 128 strain from the influent and the other in Enterobacter spp. 291 strain from the bioreactor.

Moreover, bla $_{\mathrm{PER}}$ gene was found in only a single Shewanella spp. 192 strain, which was isolated from the influent. BLASTx alignment showed its $100 \%$ sequence identity to the sequences of two variants of this type, i.e. PER-1 (CAA79968.1, Z21957) and PER-5 (ACN22483.1, FJ627180). To precisely determine $b l a_{\text {PER }}$ variant, sequencing of a larger part of the gene is needed.

Within the searched ampC genes, only bla $a_{\mathrm{CMY}}, b l a_{\mathrm{MOX}}$, $b l a_{\mathrm{FOX}}$, and $b l a_{\mathrm{ACT}}$ types were identified. In one Citrobacter sp. 403 strain, isolated from the effluent, a new variant of bla $_{\mathrm{MOX}-13}$ gene was identified (MF795086). Amino acid sequence was $99 \%$ identical to six unclassified sequences from class C $\beta$-lactamases of CMY-1/MOX family from Aeromonas spp. (WP_052815126.1, WP_042880807.1, WP_041215611.1, KEP89560.1, OJW64298.1, WP_045525552.1). The most closely related MOX variant was MOX-12 with $98 \%$ sequence identity (WP_043155783.1) to the new variant with seven amino acid changes (Fig. 1S). Moreover, a new $\beta$-lactamase gene

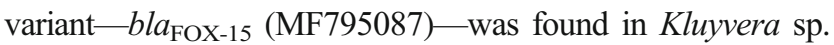
453 isolated from the effluent. In this case, the amino acid sequence was $97 \%$ identical to that of FOX-2 variant (WP 032489067.1). Differences in 12 amino acids were identified between the two sequences (Fig. 2S). Another AmpC bla gene belonged to bla $a_{\mathrm{ACT}}$ type and was found in Enterobacter sp. 327 isolated from the bioreactor. However, $b l a_{A C T}$ genes are intrinsic to Enterobacter spp. This $\beta$-lactamase determinant showed $100 \%$ sequence identity to many different ACT variants, e.g., ACT-21 (AHA80106.1, KF526118) and ACT-23 (AGU38146.1, KF515536). However, it was impossible to unambiguously determine the variant.

The most numerous and diverse $a m p C$ gene type was $b l a_{\mathrm{CMY}}$, which was observed in eight strains belonging mostly to Citrobacter spp., to which bla $a_{\mathrm{CMY}}$ is intrinsic. The identified bla genes encoded eight different amino acid sequences with one new variant of a CMY family $\beta$-lactamase. Based on the obtained sequences, the following four variants of CMY $\beta$ lactamases were unambiguously determined: CMY-139 (AMK49571.1, KU641016.1) from Citrobacter sp. T10, CMY40 (EU515251, EU515251.1) from Citrobacter sp. 323A, CMY39 (BAF95726.1, AB372224) from Citrobacter sp. 424, and CMY-4 (CAA75402.1, Y15130) from Citrobacter sp. 106. Three strains from raw wastewater carried $b l a_{\mathrm{CMY}}$ whose sequences were $100 \%$ identical to the sequences of more than one CMY variant. The bla $a_{\mathrm{CMY}}$ sequence from Escherichia sp.129 was identical to the sequences of CMY-42
(ADM21467.1, HM146927), CMY-145 (WP 075985684.1, NG_052649.1), and CMY-146 (WP_075985683.1, NG_052648.1). The bla $_{\mathrm{CMY}}$ sequence from Citrobacter sp. 122 was identical to the sequences of CMY-2 (CAA62957.1, X91840), CMY-53 (ADQ38362.1, HQ336940), and a couple of other variants. The bla $a_{\mathrm{CMY}}$ sequence from Citrobacter sp. 136 was identical to the sequences of CMY-65 (AEI52842.1, JF780936), CMY-75 (AFK73434.1, JQ733572), CMY-89 (WP_063859891.1, NG_048886.1), and CMY-113 (AIT76089.1, KM087836). Finally, in Citrobacter sp. 101 strain, a new variant of $b l a_{\mathrm{CMY}-157}$ gene (MF795088) was identified and its amino acid sequence shared $99 \%$ identity with two unclassified CMY family $\beta$-lactamases from Citrobacter spp. (WP_061067088.1, WP_048212911.1) (Fig. 3S). However, compared to one of the closest variants of CMY family $\beta$ lactamase - CMY-34 (ABN51006.1, EF394370.1) — at the sequence level, CMY-157 differed in 25 amino acids. This major change indicates the need for a further phenotypical analysis of this variant.

Furthermore, bla $a_{\mathrm{VIM}}$ genes, which encode VIM metallo- $\beta$ lactamase, were identified in seven strains from all three sampling points. It was impossible to determine the variants unambiguously, but two identical amino acid sequences were observed. In Pseudomonas sp. 164 strain from the influent, and two strains from the bioreactor (Citrobacter sp. 383 and Pseudomonas sp. 378), the observed bla $a_{\mathrm{VIM}}$ sequences were $100 \%$ identical to those of VIM-2 (AAF61483.1, AF191564) and different variants carrying an identical amino acid sequence within this fragment of the protein. A second group of four strains (one from the bioreactor and three from the effluent) carried $b l a_{\mathrm{VIM}}$ whose amino acid sequences were $100 \%$ identical to those of VIM-1 $\beta$-lactamase (CAB46686.1, Y18050), VIM-4 (AAN04257.1, AY135661.1), and different variants with identical amino acid sequence of this fragment.

Also, bla genes that belong to the bla $a_{\mathrm{KPC}}$ type were found in 13 strains, mostly from the bioreactor. All bla $a_{\mathrm{KPC}}$ genes observed in the bioreactor were found in Raoultella spp. strains, and sequence alignment using BLASTx showed $100 \%$ identity with KPC-2 (AAK70220.1, AY034847), KPC-3 (AAL05630.1, AF395881), and a couple of different variants. One Citrobacter sp. 424 strain from the effluent also possessed a bla $a_{\mathrm{KPC}}$ gene with the same amino acid sequence as in $\beta$-lactamases from the bioreactor.

The last group of identified bla genes belonged to the $b l a_{\text {ORN }}$ type of chromosomal $\beta$-lactamases characteristic of Raoultella ornithinolytica. All genes were found in Raoultella spp., including three strains from the raw wastewater and ten from the bioreactor.

Besides the identification of $\beta$-lactamase resistance genes, also the presence of I, II, and III type integrase genes was determined. As a result, all three types of integrase genesintI1, intI2, and intI3 - were observed with the highest representation of intIl (66\% of strains) (Table 1). Only intI1 and 
intI3 types were found at all three sampling points. The IntI2 genes were identified in only seven strains from the influent, but the strains belonged to various genera, i.e., Escherichia sp., Enterobacter sp., Klebsiella sp., and Raoultella spp.

\section{Antibiotic susceptibility profiles}

Among 53 strains whose antibiotic susceptibility profiles were determined, unsusceptibility to third generation cephalosporins, such as ceftazidime $(91 \%)$ and cefotaxime $(85 \%)$, was the most abundant (Table 2). Numerous strains were also unsusceptible to aztreonam (81\%). On the other hand, only $6 \%$ of strains were unsusceptible to amikacin, which was the lowest percentage of resistance among all the antibiotics tested. Multidrug resistance strains represented $41 \%$ of all the studied strains. The MAR index showed that each strain was unsusceptible to from three to ten antibiotics simultaneously, with the highest percentage (24\%) of strains unsusceptible to six antibiotics (Tables 1S-3S). Based on statistical analysis results, there were significantly more strains unsusceptible to cefotaxime in the effluent than in the influent $(p<0.05)$. Furthermore, strains unsusceptible to all three carbapenems (ertapenem, imipenem, and meropenem) were significantly more abundant in the bioreactor than in the influent $(p<0.05)$. Finally, there was a statistically significant $(p<0.05)$ reduction in the number of MDR strains between the influent and the effluent, from 48 to $44 \%$ (Table 2).

\section{Genomic localization of $\beta$-lactamase resistance genes}

Extrachromosomal replicons were isolated from $79 \%$ of all the studied strains (46 out of 58), including 21 strains from the influent, 18 strains from the bioreactor, and seven strains from the effluent. Most of the strains isolated from the three sampling points appeared to have more than one extrachromosomal replicon. The number of different plasmid profiles identified in the influent, bioreactor, and effluent samples was 21,12 , and 7 , respectively, indicating unique plasmid profiles in most of the strains. In the bioreactor, there were four different profiles, which were found in Raoultella spp. strains: the first profile in
Raoultella sp. 210C, Raoultella sp. 213C, Raoultella sp. 382A, and Raoultella sp. 293; the second in Raoultella sp. 274B, Raoultella sp. 376, and Raoultella sp. 286; the third in Raoultella sp. 385A, Raoultella sp. 299A, and Raoultella sp. 328; and the fourth in Raoultella sp. 228A (Fig. 4S).

The results of Southern blot hybridization indicated that most of the identified bla genes were located on chromosomes. However, several $b l a_{\mathrm{GES}}$ and one $b l a_{\mathrm{FOX}}$ gene were detected in extrachromosomal DNA. Firstly, one $b l a_{\mathrm{FOX}-15}$ gene from Kluyvera sp. 435 from the effluent was observed on a plasmid. Moreover, $b l a_{\mathrm{GES}}$ genes were identified in ten Raoultella spp. plasmids from bioreactor samples (Table 3). Besides four plasmid profiles of these strains, the $b l a_{\mathrm{GES}}$ signal was detected on one particular plasmid band that these strains have in common (Fig. 4S).

\section{Discussion and conclusions}

Antibiotic resistant bacteria and antibiotic resistance genes are heavily discharged into municipal sewage systems with wastewater of different origins (Kümmerer 2009). Therefore, ARGs from all main groups, including tetracycline, aminoglycoside, quinolone, and $\beta$-lactam resistance genes, have been found in this environment (Zhang et al. 2009). Moreover, wastewater microbiota is mainly composed of bacteria of human origin, including commensal and pathogenic strains. Antibiotic resistance genes in WWTPs have been identified among various pathogenic bacteria, e.g., Pseudomonas spp., Enterobacteriaceae, Staphylococcus spp., enterococci, and Aeromonas spp. (Igbinosa and Okoh 2012; Picão et al. 2013; Varela et al. 2016; Oravcova et al. 2017; Ben Said et al. 2017). With this in mind, we decided to identify $\beta$ lactamase profiles and analyze the fate of these ARGs in bacteria isolated from samples collected from UWTP. We also sought to compare these results with those of previous studies.

Based on the available literature, seven of the bla genes identified in this study were found for the first time in bacteria isolated from a WWTP. These were as follows: $b l a_{\mathrm{TEM}-12}, b l a_{\mathrm{TEM}-}$ ${ }_{30}, b l a_{\mathrm{TEM}-47 / 68}$, and $b l a_{\mathrm{ACT}}$ and within them there were three

Table 2 Percentage (\%) of phenotypically unsusceptible strains of Enterobacteriaceae and Acinetobacter sp. isolated from influent, bioreactor and effluent of UWTP

\begin{tabular}{llllllllllllll}
\hline Sampling point & CTX & CAZ & FEP & ATM & ERT & IMP & MEM & CIP & TE & C & CN & AK & MDR >3 \\
\hline Influent & $72 \mathrm{a}$ & $88 \mathrm{a}$ & $48 \mathrm{a}$ & $80 \mathrm{a}$ & $0 \mathrm{a}$ & $0 \mathrm{a}$ & $0 \mathrm{a}$ & $16 \mathrm{a}$ & $44 \mathrm{a}$ & $28 \mathrm{a}$ & $32 \mathrm{a}$ & $4 \mathrm{a}$ & $48 \mathrm{a}$ \\
Bioreactor & $95 \mathrm{ab}$ & $90 \mathrm{a}$ & $35 \mathrm{a}$ & $90 \mathrm{a}$ & $55 \mathrm{~b}$ & $50 \mathrm{~b}$ & $65 \mathrm{~b}$ & $20 \mathrm{a}$ & $35 \mathrm{a}$ & $15 \mathrm{a}$ & $15 \mathrm{a}$ & $0 \mathrm{a}$ & $30 \mathrm{~b}$ \\
Effluent & $100 \mathrm{~b}$ & $100 \mathrm{a}$ & $67 \mathrm{a}$ & $67 \mathrm{a}$ & $22 \mathrm{ab}$ & $44 \mathrm{ab}$ & $22 \mathrm{ab}$ & $22 \mathrm{a}$ & $44 \mathrm{a}$ & $11 \mathrm{a}$ & $22 \mathrm{a}$ & $22 \mathrm{a}$ & $44 \mathrm{~b}$ \\
Summary & 87 & 91 & 46 & 81 & 24 & 26 & 28 & 19 & 41 & 20 & 24 & 6 & 41 \\
\hline
\end{tabular}

Values within a column marked with different letters are significantly different $(p<0.05)$

CTX cefotaxime, CAZ ceftazidime, FEP cefepime, AZT aztreonam, ERT ertapenem, IMP imipenem, MEM meropenem, CIP ciprofloxacin, TET tetracycline, $C$ chloramphenicol, $C N$ gentamicin, $A K$ amikacin, $M D R$ multidrug resistance strains 
Table 3 Characterization of Raoultella spp. strains isolated from bioreactor

\begin{tabular}{|c|c|c|c|c|c|c|}
\hline Strain & Identification & $\begin{array}{l}\text { Antibiotic resistance } \\
\text { phenotype }\end{array}$ & $\beta$-Lactamase genes & $\begin{array}{l}\text { Integrase } \\
\text { gene }\end{array}$ & $\begin{array}{l}\text { Plasmid } \\
\text { replicon }\end{array}$ & $\begin{array}{l}\text { Plasmid } \\
\text { localization } \\
\text { of ARG }\end{array}$ \\
\hline $210 \mathrm{C}$ & $\begin{array}{l}\text { Raoultella sp. } \\
\quad \text { (MF457856) }\end{array}$ & $\begin{array}{l}\text { CTX, CAZ, ATM, ERT, IMP, } \\
\text { MEM }\end{array}$ & $\begin{array}{l}\text { bla } a_{\mathrm{TEM}-1-\text { like }}, \text { bla }_{\mathrm{GES}}, \\
\text { bla }_{\mathrm{KPC}-2-\mathrm{like}}, \text { bla }_{\mathrm{ORN}}\end{array}$ & - & + & $b l a_{\mathrm{GES}}$ \\
\hline $213 \mathrm{C}$ & $\begin{array}{l}\text { Raoultella sp. } \\
\quad \text { (MF457857) }\end{array}$ & $\begin{array}{l}\text { CTX, CAZ, FEP, ATM, ERT, } \\
\text { IMP, MEM, CIP }\end{array}$ & $\begin{array}{l}\text { bla } a_{\mathrm{TEM}-1-\text { like }}, \text { bla }_{\mathrm{GES}}, \\
\text { bla }_{\mathrm{KPC}-2-\text { like }}, \text { bla }_{\mathrm{ORN}}\end{array}$ & intI1 & + & $b l a_{\mathrm{GES}}$ \\
\hline $228 \mathrm{~A}$ & $\begin{array}{l}\text { Raoultella sp. } \\
\quad \text { (MF457858) }\end{array}$ & $\begin{array}{l}\text { CTX, CAZ, FEP, ATM, ERT, } \\
\text { IMP, MEM }\end{array}$ & $\begin{array}{l}\text { bla }_{\mathrm{TEM}-1-\text { like }} \\
\text { bla }_{\mathrm{KPC}-2 \text {-like }}\end{array}$ & - & + & - \\
\hline 274B & $\begin{array}{l}\text { Raoultella sp. } \\
\quad \text { (MF457859) }\end{array}$ & $\begin{array}{l}\text { CTX, CAZ, ATM, ERT, IMP, } \\
\text { MEM }\end{array}$ & $\begin{array}{l}\text { bla }_{\mathrm{TEM}-1-\text { like }}, b l a_{\mathrm{GES}}, \\
\text { bla }_{\mathrm{KPC}-2-\text { like }}, \text { bla } a_{\mathrm{ORN}}\end{array}$ & - & + & $b l a_{\mathrm{GES}}$ \\
\hline 328 & $\begin{array}{l}\text { Raoultella sp. } \\
\quad \text { (MF457860) }\end{array}$ & CTX, CAZ, ATM, MEM & $\begin{array}{l}\text { bla } a_{\mathrm{TEM}-1-\text { like }}, b l a_{\mathrm{GES}}, \\
\text { bla }_{\mathrm{KPC}-2 \text {-like }}, \text { bla } a_{\mathrm{ORN}}\end{array}$ & - & + & $b l a_{\mathrm{GES}}$ \\
\hline 376 & $\begin{array}{l}\text { Raoultella sp. } \\
\quad \text { (MF457861) }\end{array}$ & $\begin{array}{l}\text { CTX, CAZ, ATM, ERT, IMP, } \\
\text { MEM }\end{array}$ & $\begin{array}{l}\text { bla } a_{\mathrm{TEM}-1-\text { like }}, \text { bla }_{\mathrm{GES}}, \\
\text { bla }_{\mathrm{KPC}-2-\text { like }}, \text { bla }_{\mathrm{ORN}}\end{array}$ & - & + & $b l a_{\mathrm{GES}}$ \\
\hline $382 \mathrm{~A}$ & $\begin{array}{l}\text { Raoultella sp. } \\
\quad \text { (MF457862) }\end{array}$ & $\begin{array}{l}\text { CTX, CAZ, ATM, ERT, IMP, } \\
\text { MEM, TET, C }\end{array}$ & $\begin{array}{l}\text { bla } a_{\mathrm{TEM}-1-\text { like }}, \text { bla }_{\mathrm{GES}}, \\
\text { bla }_{\mathrm{KPC}-2-\mathrm{lik}}, \text { bla }_{\mathrm{ORN}}\end{array}$ & intI1 & + & $b l a_{\mathrm{GES}}$ \\
\hline $385 \mathrm{~A}$ & $\begin{array}{l}\text { Raoultella sp. } \\
\quad \text { (MF457863) }\end{array}$ & CTX, CAZ, ATM, ERT, MEM & $\begin{array}{l}\text { bla } a_{\mathrm{TEM}-1-\text { like }}, \text { bla }_{\mathrm{GES}}, \\
\text { bla }_{\mathrm{KPC}-2 \text {-like }}, \text { bla }_{\mathrm{ORN}}\end{array}$ & - & + & $b l a_{\mathrm{GES}}$ \\
\hline 286 & $\begin{array}{l}\text { Raoultella sp. } \\
\quad \text { (MF457864) }\end{array}$ & $\begin{array}{l}\text { CTX, CAZ, ATM, ERT, IMP, } \\
\text { MEM }\end{array}$ & 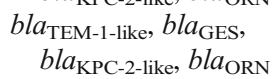 & - & + & $b l a_{\mathrm{GES}}$ \\
\hline 293 & $\begin{array}{l}\text { Raoultella sp. } \\
\quad \text { (MF457865) }\end{array}$ & $\begin{array}{l}\text { CTX, CAZ, FEP, ATM, ERT, } \\
\text { IMP, MEM, TET }\end{array}$ & $\begin{array}{l}b l a_{\mathrm{TEM}-1-\mathrm{like}}, b l a_{\mathrm{GES}}, \\
\text { bla }_{\mathrm{KPC}-2-\mathrm{lik}}, b l a_{\mathrm{ORN}}\end{array}$ & intII & + & $b l a_{\mathrm{GES}}$ \\
\hline 299A & $\begin{array}{l}\text { Raoultella sp. } \\
\quad \text { (MF457866) }\end{array}$ & CTX, CAZ, ATM, MEM & $\begin{array}{l}b l a_{\mathrm{TEM}-1-\mathrm{like}}, b l a_{\mathrm{GES}}, \\
\left.\text { bla }_{\mathrm{KPC}-2-\mathrm{lik}},{ }\right) a_{\mathrm{ORN}}\end{array}$ & - & + & $b l a_{\mathrm{GES}}$ \\
\hline
\end{tabular}

new variants: $b l a_{\mathrm{CMY}-157}, b l a_{\mathrm{MOX}-13}$, and $b l a_{\mathrm{FOX}-15}$. What is worth noting is that $b l a_{\text {TEM-12 }}$ was previously detected in numerous clinical isolates of Enterobacteriaceae, e.g., Escherichia coli, Klebsiella spp., or Enterobacter spp. (Sturm et al. 2010; Perilli et al. 2011). In our study, bla $a_{\mathrm{TEM}-12}$ was found in Shewanella spp., which is the first case of this variant in this species ever. Another variant, $b l a_{\mathrm{TEM}-30}$, was also found in clinical strains of Enterobacteriaceae, with high frequency of isolates in Spain (Martín et al. 2010; Ortega et al. 2012) and minor identifications in Israel, the UK (NZ_FLMS01000013.1), Sweden (NZ_KE701793.1), Portugal (NG_050260.1), Vietnam (NZ_CZLO01000043.1), the USA, and Poland (Bradford et al. 2004; Empel et al. 2008; Leavitt et al. 2009).

Both $b l a_{\text {TEM-47 }}$ and $b l a_{\text {TEM-68 }}$ were previously identified mostly in clinical strains of Enterobacteriaceae in Polish hospitals (Gniadkowski et al. 1998; Baraniak et al. 2005; Robin et al. 2012). The $b l a_{\text {TEM-68 }}$ variant probably evolved from $b l a_{\text {TEM-47, }}$, and both are not very frequent in Poland. Outside this area, there was a report from Canada, where $b l a_{\mathrm{TEM}-47}$ was found in Streptococcus dysgalactiae (Vélez et al. 2017). To the best of our knowledge, this study reports the first isolate carrying a

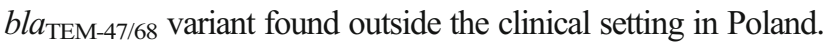

Fifty-three variants of ACT $\beta$-lactamase have been identified so far in numerous bacterial species. However, little is known about the dissemination of this $\beta$-lactamase in an aqueous environment. Amador et al. (Amador et al. 2015) found bla $a_{\mathrm{EBC}}$ gene, including $b l a_{\mathrm{ACT}}$, the most prevalent gene of the AmpC $\beta$ lactamase type $(38.9 \%)$. There was also a report on $b l a_{\mathrm{ACT}-13}$ gene that was found in Enterobacter asburiae isolated from a water distribution network (Manageiro et al. 2014). Hence, our identification of bla $a_{\mathrm{ACT}}$ in Enterobacter sp. is the first isolation of this $\beta$-lactamase gene from a wastewater environment.

All the new bla variants $\left(b l a_{\mathrm{FOX}-15}, b l a_{\mathrm{MOX}-13}\right.$, and $b l a_{\mathrm{CMY}-}$ ${ }_{157}$ ) belong to class $\mathrm{C}$ serine $\beta$-lactamases-AmpC-and have motifs characteristic of this class, such as SXSK motif (typical of AmpC active site), YXN motif (characteristic of the C class), and KTG domain (Ghuysen 1991). The bla $a_{\mathrm{FOX}-15}$ and $b a_{\mathrm{MOX}-13}$ variants are more similar to the remaining variants of the FOX and MOX types of $\beta$-lactamases, respectively, than is $b l a_{\mathrm{CMY}-157}$ to the CMY type. In the CMY-157 sequence, we found 12 unique amino acid differences compared to the sequences of other CMY variants (Fig. 3S). However, the sequence of a putative signal peptide (first 20 aa) is highly similar to the consensus sequence of CMY family. To conclusively confirm that CMY-157 is a member of the CMY family, additional phenotypical tests are needed. The identification of $b l a_{\mathrm{FOX}-15}$ on a small plasmid in Kluyvera $\mathrm{sp}$. is - to our knowledge - the first observation of bla $a_{\mathrm{FOX}}$ in this genus.

The case of $b l a_{\mathrm{TEM}-116}$, which was recently widely discussed by a couple of researchers (Jacoby and Bush 2016; Pleiss and Zeil 2016; Furlan et al. 2017), is also worth noting. The problem with this variant concerns possible false-positive results caused by contamination of a PCR reaction with a commercial Taq polymerase. The $b l a_{\mathrm{TEM}-116}$ variant was developed synthetically and cloned into pUC vectors as a selection gene (selection with ampicillin). Production of Taq polymerase is based on vectors that contain the $b l a_{\text {TEM-116 }}$ gene, which could be the cause of false-positive identifications of this variant in the clinical or 
natural environment. However, the bla $a_{\mathrm{TEM}-116}$ variant was recently identified in numerous genome sequences from the natural environment (NZ_ADUV01000033.1, NZ NDGT01000042, NZ AKVH01000020.1, NZ LATZ01000118.1). Consequently, sequencing of a PCR product is - in our opinion - insufficient to prove the presence of $b l a_{\mathrm{TEM}-116}$ in natural habitats. Only sequencing of a whole genome or a metagenome approach could produce conclusive results.

Moreover, three types of integrase genes were found in this study, but only intII and intI3 were identified at all three sampling points. While intI2 genes were also found, they were detected only in raw wastewater samples. Based on literature data, intI2 is less frequently observed in wastewater samples than intI1 (Moura et al. 2007; Su et al. 2014). That relationship was also observed in our study.

In this study, an interesting group of highly resistant Raoultella spp. strains from a bioreactor was observed (Table 3). Raoultella spp. are gram-negative aerobic rods belonging to the Enterobacteriaceae family. They typically inhabit natural environments but were also recognized as opportunistic human pathogens (Sękowska 2017). These bacteria are naturally resistant to aminopenicillins because of the possession of chromosomal, class A $\beta$-lactamase genes (Walckenaer et al. 2004). Additionally, many different $\beta$-lactamase genes have been reported in this genus so far, including $b l a_{\mathrm{TEM}}, b l a_{\mathrm{SHV}}$, bla $_{\mathrm{CTX}-\mathrm{M}}$, bla $_{\mathrm{IMP}}, b l a_{\mathrm{KPC}}, b l a_{\mathrm{NDM}}, b l a_{\mathrm{OXA}}$, and $b l a_{\mathrm{OXA}-48}$ (Zurfluh et al. 2013; Sun et al. 2015; Demiray et al. 2016; Yao et al. 2017). In this study, $b l a_{\mathrm{TEM}}, b l a_{\mathrm{GES}}, b l a_{\mathrm{KPC}}$, and $b l a_{\mathrm{ORN}}$ genes characteristic of $R$. ornithinolytica were identified in all of the strains with the exception of one (228A). The results of molecular determinants analysis were also convergent with those of phenotypical tests, where all Raoultella spp. strains were unsusceptible to third-generation cephalosporins (ceftazidime and cefotaxime), aztreonam (monobactam), and meropenem (carbapenem). Moreover, this is the first identification of bla $a_{\mathrm{GES}}$ in Raoultella spp. and, additionally, in ten of the isolated strains, this gene has been located on small plasmids ( $\sim 9 \mathrm{~kb})$. B-lactamase genes had been identified on a couple of Raoultella spp. big plasmids and megaplasmids before $\left(b l a_{\mathrm{IMP}-4}\right.$ and $b l a_{\mathrm{KPC}-2}$ on $450 \mathrm{~kb}$ plasmid, $b l a_{\mathrm{NDM}-1}$ on $41 \mathrm{~kb}$ and $100 \mathrm{~kb}$ plasmids, $b l a_{\mathrm{OXA}-48}$ on $63 \mathrm{~kb}$ or $b l a_{\mathrm{KPC}-2}$ $40 \mathrm{~kb}$ plasmid) (Sun et al. 2015; Zheng et al. 2015; Yao et al. 2017). However, this is the first observation of a bla gene on a very small plasmid in Raoultella spp.

Numerous $\beta$-lactamases whose genes (bla) were identified among the isolated strains belonged to all four principal classes of these enzymes: A, B, C, and D according to the Ambler classification (Bush and Jacoby 2010). Of the identified bla genes, only $b l a_{\text {TEM-1-like }}$ and $b l a_{\text {OXA }}$ were found at all three sampling points (raw wastewater, bioreactor, and effluent). However, statistical analysis results indicated no significant differences in the frequency of bla genes between samples from different parts of the WWTP. Similar results were observed in a previous study for Aeromonas spp. (Piotrowska et al. 2017), in which eight bla class A genes (bla $a_{\mathrm{TEM}-1-\mathrm{like}}$, $b l a_{\mathrm{SHV}-11-l i k e}, b l a_{\mathrm{SHV}-12-l i k e}, b l a_{\mathrm{CTX}-\mathrm{M}-15-\mathrm{like}}, b l a_{\mathrm{CTX}-\mathrm{M}-27-\text { like }}$, $\left.b l a_{\mathrm{GES}}, b l a_{\mathrm{PER} 1 / 5}, b l a_{\mathrm{KPC} 2-1 \mathrm{ike}}\right)$ and one class D gene $\left(b l a_{\mathrm{OXA}}\right)$ were found. Such a result suggests the possible transmission of the mentioned bla genes between these groups of bacteria. However, in this study, results of antibiotic susceptibility testing indicated significantly fewer MDR isolates (43\%) than in the Aeromonas spp. study (68\%) (Piotrowska et al. 2017). The main reason for that was a decrease in the susceptibility to antibiotics other than the $\beta$-lactams, i.e., ciprofloxacin, chloramphenicol, and amikacin. At the same time, significantly more bacteria were unsusceptible to most of the $\beta$-lactams (besides cefepime) and at least $60 \%$ of strains were unsusceptible to cephalosporins and monobactam. This result indicates that $\beta$-lactam resistance in the studied WWTP is more likely maintained among gram-negative rods than in Aeromonas spp. Differences between phenotypical and molecular results could be explained by the presence of molecular determinants that were not found among the isolated strains, both specific ones (various $\beta$-lactamases) or those with a wider range of specificity (efflux-pumps).

In conclusion, $\beta$-lactamase genes are widely disseminated among potentially pathogenic gram-negative rods isolated from a WWTP, which survive the wastewater treatment process and are released into the aquatic environment. The finding of 116 genes that encode enzymes belonging to $12 \beta$ lactamase types confirms this statement, especially since three new variants of $\beta$-lactamase genes ( $b l a_{\mathrm{CMY}-157}, b l a_{\mathrm{MOX}-13}$, and $\left.b l a_{\mathrm{FOX}-15}\right)$ were identified. Moreover, the identification of four bla genes that have never been found in a WWTP before $\left(b l a_{\mathrm{TEM}-12}, b l a_{\mathrm{TEM}-30}, b l a_{\mathrm{TEM}-47 / 68}, b l a_{\mathrm{ACT}}\right)$ reveals hazardous potential and continuous variability of this environment. Importantly, nine bla genes were previously found in the same environment in Aeromonas spp. (bla $a_{\mathrm{TEM}-1-\mathrm{like}}$, $b l a_{\mathrm{SHV}-11-l i k e}, b l a_{\mathrm{SHV}-12-l i k e}, b l a_{\mathrm{CTX}-\mathrm{M}-15-\mathrm{like}}, b l a_{\mathrm{CTX}-\mathrm{M}-27-\text { like, }}$, $\left.b l a_{\mathrm{GES}}, b l a_{\mathrm{PER} 1 / 5}, b l a_{\mathrm{KPC}-2-\text { like }}, b l a_{\mathrm{OXA}}\right)$, which indirectly indicates the possible dissemination of bla genes between different bacterial genera. The identification of $b l a_{\mathrm{FOX}-15}$ and $b l a_{\mathrm{GES}}$ within mobile genetic elements (small plasmids) is alarming. Whereas plasmid contribution to horizontal gene transfer (HGT) is undeniable, evaluation of the scale of this process and characterization of mobilomes in particular environments and bacterial hosts are important for understanding HGT mechanisms. Culture-based approach employed in this study enabled us to demonstrate the occurrence of small plasmids in Kluyera spp. and Raoultella spp., which was the first observation of bla $a_{\mathrm{FOX}-15}$ and $b l a_{\mathrm{GES}}$ genes within these genera. This result shows the correlation that is missing in a metagenomic approach. Finally, this approach shows that besides the decrease in the number of MDR strains in the effluent compared to the influent and the significantly higher 
number of cefotaxime and carbapenem unsusceptible strains in the influent, no differences in the frequency of diverse types of bla genes between the isolation points were found. This is another disturbing observation that supports the hypothesis of WWTPs as hot spots for ARG and ARB dissemination.

Acknowledgements The authors would like to thank the Warsaw Wastewater Treatment Plant (Warsaw, Poland) and the National Medicines Institute for providing wastewater samples and DNA for the positive controls in a PCR assay, respectively. The authors would also like to acknowledge the COST Action ES1403 NEREUS "New and emerging challenges and opportunities in wastewater reuse," supported by COST (European Cooperation in Science and Technology, www.cost.eu), for stimulating the work presented in this paper.

Funding This research was financed by the grants from the National Science Centre, Poland (UMO-2014/15/N/NZ9/00439;741/N-COST/ 2010/0).

\section{Compliance with ethical standards}

The authors declare that they have no conflict of interest. This article does not contain any studies with human participants or animals performed by any of the authors. Informed consent was obtained from all individual participants included in the study.

Open Access This article is distributed under the terms of the Creative Commons Attribution 4.0 International License (http:// creativecommons.org/licenses/by/4.0/), which permits unrestricted use, distribution, and reproduction in any medium, provided you give appropriate credit to the original author(s) and the source, provide a link to the Creative Commons license, and indicate if changes were made.

Publisher's note Springer Nature remains neutral with regard to jurisdictional claims in published maps and institutional affiliations.

\section{References}

Altschul SF, Gish W, Miller W et al (1990) Basic local alignment search tool. J Mol Biol 215:403-410. https://doi.org/10.1016/S00222836(05)80360-2

Amador PP, Fernandes RM, Prudêncio MC et al (2015) Antibiotic resistance in wastewater: occurrence and fate of Enterobacteriaceae producers of class A and class C $\beta$-lactamases. J Environ Sci Health Part A Tox Hazard Subst Environ Eng 50:26-39. https://doi.org/10. 1080/10934529.2015.964602

Aminov RI, Mackie RI (2007) Evolution and ecology of antibiotic resistance genes. FEMS Microbiol Lett 271:147-161. https://doi.org/10. $1111 / j .1574-6968.2007 .00757 . x$

Baquero F, Martínez J-L, Cantón R (2008) Antibiotics and antibiotic resistance in water environments. Curr Opin Biotechnol 19:260 265. https://doi.org/10.1016/j.copbio.2008.05.006

Barancheshme F, Munir M (2017) Strategies to combat antibiotic resistance in the wastewater treatment plants. Front Microbiol 8:2603. https://doi.org/10.3389/fmicb.2017.02603

Baraniak A, Fiett J, Mrówka A et al (2005) Evolution of TEM-type extended-spectrum beta-lactamases in clinical Enterobacteriaceae strains in Poland. Antimicrob Agents Chemother 49:1872-1880. https://doi.org/10.1128/AAC.49.5.1872-1880.2005
Ben Said M, Abbassi MS, Gómez P et al (2017) Staphylococcus aureus isolated from wastewater treatment plants in Tunisia: occurrence of human and animal associated lineages. J Water Health 15:638-643. https://doi.org/10.2166/wh.2017.258

Bonnet R (2004) Growing group of extended-spectrum $\beta$-lactamases: the CTX-M enzymes. Antimicrob Agents Chemother 48:1-14. https:// doi.org/10.1128/AAC.48.1.1-14.2004

Bradford PA, Bratu S, Urban C et al (2004) Emergence of carbapenemresistant Klebsiella species possessing the class A carbapenemhydrolyzing KPC-2 and inhibitor-resistant TEM-30 betalactamases in New York City. Clin Infect Dis Off Publ Infect Dis Soc Am 39:55-60. https://doi.org/10.1086/421495

Bush K, Jacoby GA (2010) Updated functional classification of betalactamases. Antimicrob Agents Chemother 54:969-976. https:// doi.org/10.1128/AAC.01009-09

CLSI (2017) M100S27 | Performance standards for antimicrobial susceptibility testing. https://clsi.org/standards/products/microbiology/ m100/. Accessed 14 Jul 2017

Dallenne C, Da Costa A, Decre D et al (2010) Development of a set of multiplex PCR assays for the detection of genes encoding important $\beta$-lactamases in Enterobacteriaceae. J Antimicrob Chemother 65: 490-495. https://doi.org/10.1093/jac/dkp498

Demiray T, Koroglu M, Ozbek A, Altindis M (2016) A rare cause of infection, Raoultella planticola: emerging threat and new reservoir for carbapenem resistance. Infection 44:713-717. https://doi.org/10. 1007/s15010-016-0900-4

Empel J, Baraniak A, Literacka E et al (2008) Molecular survey of betalactamases conferring resistance to newer beta-lactams in Enterobacteriaceae isolates from Polish hospitals. Antimicrob Agents Chemother 52:2449-2454. https://doi.org/10.1128/AAC.00043-08

European Committee on Antimicrobial Susceptibility Testing (2018) http://www.eucast.org/

Food and Agriculture Organization of the United Nations (2018) http:// www.fao.org/antimicrobial-resistance/en/

Furlan JPR, Stehling EG, Pitondo-Silva A (2017) Importance of sequencing to determine functional blaTEM variants. Antimicrob Agents Chemother 61. https://doi.org/10.1128/AAC.00237-17

Ghuysen JM (1991) Serine beta-lactamases and penicillin-binding proteins. Annu Rev Microbiol 45:37-67. https://doi.org/10.1146/ annurev.mi.45.100191.000345

Gniadkowski M (2008) Evolution of extended-spectrum beta-lactamases by mutation. Clin Microbiol Infect 14(Suppl 1):11-32. https://doi. org/10.1111/j.1469-0691.2007.01854.x

Gniadkowski M, Schneider I, Jungwirth R et al (1998) Ceftazidimeresistant Enterobacteriaceae isolates from three Polish hospitals: identification of three novel TEM- and SHV-5-type extended-spectrum beta-lactamases. Antimicrob Agents Chemother 42:514-520

Henriques IS, Fonseca F, Alves A et al (2006) Occurrence and diversity of integrons and $\beta$-lactamase genes among ampicillin-resistant isolates from estuarine waters. Res Microbiol 157:938-947. https://doi. org/10.1016/j.resmic.2006.09.003

Igbinosa IH, Okoh AI (2012) Antibiotic susceptibility profile of Aeromonas species isolated from wastewater treatment plant. Sci World J 2012:1-6. https://doi.org/10.1100/2012/764563

Jacoby GA, Bush K (2016) The curious case of TEM-116. Antimicrob Agents Chemother 60:7000-7000. https://doi.org/10.1128/AAC. 01777-16

James G (2010) Universal bacterial identification by PCR and DNA sequencing of 16S rRNA gene. In: Schuller M, Sloots TP, James GS et al (eds) PCR for clinical microbiology: an Australian and International perspective. Springer Netherlands, Dordrecht, pp 209-214

Janda JM, Abbott SL (2007) 16S rRNA gene sequencing for bacterial identification in the diagnostic laboratory: pluses, perils, and pitfalls. J Clin Microbiol 45:2761-2764. https://doi.org/10.1128/JCM.01228-07 
Khan AU, Parvez S (2014) Detection of bla(NDM-4) in Escherichia coli from hospital sewage. J Med Microbiol 63:1404-1406. https://doi. org/10.1099/jmm.0.076026-0

Kümmerer K (2009) Antibiotics in the aquatic environment — a reviewpart II. Chemosphere 75:435-441

Leavitt A, Chmelnitsky I, Colodner R et al (2009) Ertapenem resistance among extended-spectrum-beta-lactamase-producing Klebsiella pneumoniae isolates. J Clin Microbiol 47:969-974. https://doi.org/ 10.1128/JCM.00651-08

Manageiro V, Ferreira E, Caniça M, Manaia CM (2014) GES-5 among the $\beta$-lactamases detected in ubiquitous bacteria isolated from aquatic environment samples. FEMS Microbiol Lett 351:64-69. https:// doi.org/10.1111/1574-6968.12340

Martín O, Valverde A, Morosini MI et al (2010) Population analysis and epidemiological features of inhibitor-resistant-TEM-beta-lactamaseproducing Escherichia coli isolates from both community and hospital settings in Madrid, Spain. J Clin Microbiol 48:2368-2372. https://doi.org/10.1128/JCM.00608-10

Michael I, Rizzo L, McArdell CS et al (2013) Urban wastewater treatment plants as hotspots for the release of antibiotics in the environment: a review. Water Res 47:957-995. https://doi.org/10.1016/j. watres.2012.11.027

Michael-Kordatou I, Karaolia P, Fatta-Kassinos D (2018) The role of operating parameters and oxidative damage mechanisms of advanced chemical oxidation processes in the combat against antibiotic-resistant bacteria and resistance genes present in urban wastewater. Water Res 129: 208-230. https://doi.org/10.1016/j.watres.2017.10.007

Moura A, Henriques I, Ribeiro R, Correia A (2007) Prevalence and characterization of integrons from bacteria isolated from a slaughterhouse wastewater treatment plant. J Antimicrob Chemother 60: 1243-1250. https://doi.org/10.1093/jac/dkm340

Novo A, André S, Viana P et al (2013) Antibiotic resistance, antimicrobial residues and bacterial community composition in urban wastewater. Water Res 47:1875-1887. https://doi.org/10.1016/j.watres.2013.01.010

Oravcova V, Mihalcin M, Zakova J et al (2017) Vancomycin-resistant enterococci with vanA gene in treated municipal wastewater and their association with human hospital strains. Sci Total Environ 609:633-643. https://doi.org/10.1016/j.scitotenv.2017.07.121

Ortega A, Oteo J, Aranzamendi-Zaldumbide M et al (2012) Spanish multicenter study of the epidemiology and mechanisms of amoxicillinclavulanate resistance in Escherichia coli. Antimicrob Agents Chemother 56:3576-3581. https://doi.org/10.1128/AAC.06393-11

Perez-Perez FJ, Hanson ND (2002) Detection of plasmid-mediated AmpC-lactamase genes in clinical isolates by using multiplex PCR. J Clin Microbiol 40:2153-2162. https://doi.org/10.1128/ JCM.40.6.2153-2162.2002

Perilli M, Segatore B, Mugnaioli C, et al (2011) Persistence of TEM-52/ TEM-92 and SHV-12 extended-spectrum $\beta$-lactamases in clinical isolates of Enterobacteriaceae in Italy. Microb Drug Resist Larchmt N 17:521-524. doi: https://doi.org/10.1089/mdr.2011.0059

Perry JA, Wright GD (2013) The antibiotic resistance "mobilome": searching for the link between environment and clinic. Front Microbiol 4:138. https://doi.org/10.3389/fmicb.2013.00138

Picão RC, Cardoso JP, Campana EH et al (2013) The route of antimicrobial resistance from the hospital effluent to the environment: focus on the occurrence of KPC-producing Aeromonas spp. and Enterobacteriaceae in sewage. Diagn Microbiol Infect Dis 76:8085. https://doi.org/10.1016/j.diagmicrobio.2013.02.001

Piotrowska M, Przygodzińska D, Matyjewicz K, Popowska M (2017) Occurrence and variety of $\beta$-lactamase genes among Aeromonas spp. isolated from urban wastewater treatment plant. Front Microbiol 8:863. https://doi.org/10.3389/fmicb.2017.00863

Pleiss J, Zeil C (2016) Reply to "The curious case of TEM-116.". Antimicrob Agents Chemother 60:7001. https://doi.org/10.1128/ AAC.01786-16
Robin F, Hennequin C, Gniadkowski M et al (2012) Virulence factors and TEM-type $\beta$-lactamases produced by two isolates of an epidemic Klebsiella pneumoniae strain. Antimicrob Agents Chemother 56: 1101-1104. https://doi.org/10.1128/AAC.05079-11

Sękowska A (2017) Raoultella spp.-clinical significance, infections and susceptibility to antibiotics. Folia Microbiol (Praha) 62:221-227. https://doi.org/10.1007/s12223-016-0490-7

Srinivasan R, Karaoz U, Volegova M et al (2015) Use of 16S rRNA gene for identification of a broad range of clinically relevant bacterial pathogens. PLoS One 10. https://doi.org/10.1371/journal.pone.0117617

Sturm PDJ, Bochum ETM, van Mook-Vermulst SVM, et al (2010) Prevalence, molecular characterization, and phenotypic confirmation of extended-spectrum beta-lactamases in Escherichia coli, Klebsiella pneumoniae, and Klebsiella oxytoca at the Radboud University Nijmegen Medical Centre in the Netherlands. Microb Drug Resist Larchmt N 16:55-60. doi: https://doi.org/10.1089/mdr.2009.0107

Su H-C, Ying G-G, He L-Y et al (2014) Antibiotic resistance, plasmidmediated quinolone resistance (PMQR) genes and ampC gene in two typical municipal wastewater treatment plants. Environ Sci Process Impacts 16:324-332. https://doi.org/10.1039/c3em00555k

Sun F, Yin Z, Feng J et al (2015) Production of plasmid-encoding NDM-1 in clinical Raoultella ornithinolytica and Leclercia adecarboxylata from China. Front Microbiol 6:458. https://doi.org/10.3389/fmicb.2015.00458

Varela AR, Nunes OC, Manaia CM (2016) Quinolone resistant Aeromonas spp. as carriers and potential tracers of acquired antibiotic resistance in hospital and municipal wastewater. Sci Total Environ 542:665-671. https://doi.org/10.1016/j.scitotenv.2015.10.124

Vélez JR, Cameron M, Rodríguez-Lecompte JC et al (2017) Whole-genome sequence analysis of antimicrobial resistance genes in Streptococcus uberis and Streptococcus dysgalactiae isolates from Canadian dairy herds. Front Vet Sci 4:63. https://doi.org/10.3389/fvets.2017.00063

Walckenaer E, Poirel L, Leflon-Guibout V et al (2004) Genetic and biochemical characterization of the chromosomal class A beta-lactamases of Raoultella (formerly Klebsiella) planticola and Raoultella ornithinolytica. Antimicrob Agents Chemother 48:305-312

Walckenaer E, Leflon-Guibout V, Nicolas-Chanoine M-H (2008) How to identify Raoultella spp. including $R$. ornithinolytica isolates negative for ornithine decarboxylase? The reliability of the chromosomal bla gene. J Microbiol Methods 75:405-410. https://doi.org/10.1016/ j.mimet.2008.07.011

World Health Organization (2017) https:/www.who.int/antimicrobialresistance/en/

Yao Y, Lazaro-Perona F, Falgenhauer L et al (2017) Insights into a novel blaKPC-2-encoding IncP-6 plasmid reveal carbapenem-resistance circulation in several Enterobacteriaceae species from wastewater and a hospital source in Spain. Front Microbiol 8:1143. https://doi. org/10.3389/fmicb.2017.01143

Zhang X-X, Zhang T, Fang HH (2009) Antibiotic resistance genes in water environment. Appl Microbiol Biotechnol 82:397-414

Zhang S, Han B, Gu J et al (2015) Fate of antibiotic resistant cultivable heterotrophic bacteria and antibiotic resistance genes in wastewater treatment processes. Chemosphere 135:138-145. https://doi.org/10. 1016/j.chemosphere.2015.04.001

Zheng B, Zhang J, Ji J et al (2015) Emergence of Raoultella ornithinolytica coproducing IMP-4 and KPC-2 carbapenemases in China. Antimicrob Agents Chemother 59:7086-7089. https://doi. org/10.1128/AAC.01363-15

Zurfluh K, Hächler H, Nüesch-Inderbinen M, Stephan R (2013) Characteristics of extended-spectrum $\beta$-lactamase- and carbapenemase-producing Enterobacteriaceae isolates from rivers and lakes in Switzerland. Appl Environ Microbiol 79:3021-3026. https://doi.org/10.1128/AEM.00054-13 